\title{
PEMBERDAYAAN MASYARAKAT TERHADAP KESENJANGAN EKONOMI DAN SOSIAL DI LINGKUNGAN RW 08 DESA GIRIMULYA
}

\author{
Rachmatullailly, Bakri Purwadi, Dena Meilinda Sumadika \\ rachmatulaily@uika-bogor.ac.id \\ Dosen Fakultas Ekonomi ${ }^{1}$, Mahasiswa KKN Kelompok 31 Tahun $2018^{2}$
}

\begin{abstract}
ABSTRAK
Kesenjangan sosial dan ekonomi masyarakat adalah perbedaan tingkat kemampuan masyarakat baik dari segi pendapatan atau ketimpangan sosial dalam masyarakat yang menjadikan perbedan yang sangat mencolok antara masyarakat. Salah satu desa yang memiliki kesenjangan sosial dan ekonomi adalah Desa Girimulya Kecamatan Cibungbulang Kabupaten Bogor. Khususnya di RW 08 Kampung Pabuaran Semper, yaitu karena masyarakatnya bersifat individualis yang hanya memetingkan kelompok tertentu saja dan tingkat pendidikan masyarakat yang masih rendah Masalah kesenjangan sosial dan ekonomi ini memiliki tujuan yaitu: (1) menumbuhkan pemahaman dalam hal bersosialisasi dalam masyarakat,(2) meningkatkan pendapatan masyarakat melalui pelatihan industri rumah tangga dengan pendekatan religius. Metode pendekatan yang digunakan dalam kegiatan ini adalah: (1) Pendekatan religius; (2) Pendekatan organisasi
\end{abstract}

\section{Kata kunci: Kesenjangan Sosial, Peningkatan Ekonomi, Kesenjangan Ekonomi, Pendidikan Masyarakat.}

\section{PENDAHULUAN}

\section{Analisis Situasi}

Analisis situasi yang dilaksanakan merupakan upaya untuk menggali informasi, poensi dan kendala yang ada sebagai bahan acuan untuk merumuskan program kegiatan yang akan dilakukan oleh tim KKN 31 . Dari analisis situasi ini tim hal langkah awal yang diambil sebelum pelaksanaan program KKN adalah melakukan observasi guna inventarisasi keadaan lokasi KKN yang berada di desa Girimulya Kecamatan Cibungbulang observsi lingkungan desa ini dilaksanakan tanggal 2 Agustus 2018. Pada tahap Observasi mahasiswa melaukan pengamatan secara langsung kelapangan melakukan dialog dengan pihakpihak yang terkait di masyarakat dan mengamati keadaan yang menyangkut fisik maupun non fisik. Hasil yang diperoleh dari hasil observasi adalah RW 08 Desa Girimulya kecamatan cibungbulang akses jalan sudah memadai berupa jalan aspal tetapi banyak jalanan yag sudah rusak yang harus dilakukan perbaikan. Di desa Girimulya tepatnya di kampung pabuaran semper RW 08 rata penduduk bermata pencaharian Pedagang dan petani ada juga pabrik Home made yaitu pabrik tahu dan pabrik oncom sebagian lain ada yang sebagai pegawai

Selain itu kondisi di wilayah kampung pabuaran semper sedang dalam kondisi kekeringan sulit air dan akses jalan ke tempat MCK lumayan jauh, selain itu 
tidak ada penerangan disepanjang jalan menuju MCK masyarakat mandi, mencuci dan mengambil air ke tempat sumber mata air.

\section{Permasalahan yang Dihadapi}

1. Masyarakat bersifat individualis yang hanya memetingkan kelompok tertentu saja.

2. Tingkat pendidikan masyarakat yang masih rendah.

3. Sarana dan prasarana yang kurang memadai seperti kurangnya penerangan jalan menuju tempat MCK.

4. Kurangnya masyarakat pada pastisipasi acara tahunan seperti 17 Agustus.

5. Kurangnya petunjuk jalan di sekitar kampung pabuaran semper desa girimulya RW 08.

6. Kurangnya pemahaman dalam membaca kitab suci AL-Qur'an dan Iqro.

7. Rentannya anak-anak terhadap perilaku hidup bersih dan sehat.

8. Sulitnya partisipasi perekonomian pada masyarakat kampung pabuaran semper RW 08.

\section{Solusi yang Ditawarkan}

1. Mengadakan kegiatan Pos Ronda pada setiap RT khususnya pada warga RW 08.

2. Mengadakan kegiatan membaca oleh anak-anak di Mushola RT 03.

3. Pemasangan Penerangan Jalan Umum untuk akses menuju MCK.

4. Mengadakan Lomba 17 Agustus dan merayakan pentas yang bertujuan untuk menumbuhkan mental karakteristik jiwa muda dan memperat tali silaturahmi warga RW 08 Kampung Pabuaran Semper.
5. Membuat Plang petunjuk jalan guna mempermudah masyarakat untuk mengetahui lokasi yang dituju.

6. Mengadakan TPA untuk mempelajari dan membaca kitab suci AL-Qur'an dan Iqro.

7. Mengadakan penyuluhan kesehatan cuci tangan di SDN Leuweung Kolot 3.

8. Mengadakan Pelatihan Batik Jumputan untuk Ibu-ibu di RW 08.

\section{Keadaan Geografis}

Luas Wilayah : 122,03 Ha

- Tiga (3) Dusun

- Delapan (8) Rukun Warga (RW)

- Tiga Puluh (30) Rukun Tetangga (RT)

Batas Wilayah

Batas Utara : Desa Leuweung Kolot/Jalan Provinsi

Batas Selatan : Desa Cibatok/Kecamatan Cibungbulang

Batas Barat : Desa Cimanggu 1/Sungai Ciaruteun

Batas Timur : Desa Cibatok

Jumlah Penduduk: 9.119 Jiwa

\section{Kondisi Masyarakat}

Jumlah Penduduk Desa Girimulya tercatat sebanyak 9.119 Jiwa terdiri dari :
1. Laki-Laki
: 4.735 Jiwa
2. Perempuan
: 4.384 Jiwa
3. Jumlah Kepla Keluarga (KK): 2.671

\section{Jumlah Penduduk Berdasarkan Mata}

\section{Pencaharian :}

1. Petani

: 123 Orang

2. Pedagang

: 1.400 Orang

3. (PNS)

: 55 Orang

4. TNI/Polri : 12 Orang

5. Pensiunan : 15 Orang

6. Buruh Pabrik : 523 Orang

7. Pengarajin :231 Orang

8. Tukang Bangunan: 25 Orang 

9. Penjahit :5 Orang
10. Tukang Las : 4 Orang
11. Tukang Ojek : 135 Orang
12. Bengkel : 5 Orang
13. Sopir $: 27$ Orang
14. Lain-lain :642 Orang

\section{Jumlah Penduduk Menurut tingkat} pendidikan

1. Belum Sekolah :926 Orang

2. Tidak tamat SD :279 Orang

3. Tamat SD :4.295 Orang

4. Tamat SLTP :2.528 Orang

5. Tamat SLTA :986 Orang

6. Tamat Akademi : 5 Orang

7. Tamat Perguruan Tinggi/ SI: 57

Orang

8. Tamat Perguruan Tinggi/ S2: 38

Orang

9. Tamat Perguruan Tinggi/ S3: 5

Orang 


\section{METODE PELAKSANAAN}

Tahapan Pelaksanaan

Tahapan pelaksanaan untuk kegiatan ini sebagaimana terlihat pada bagan sebagai berikut:

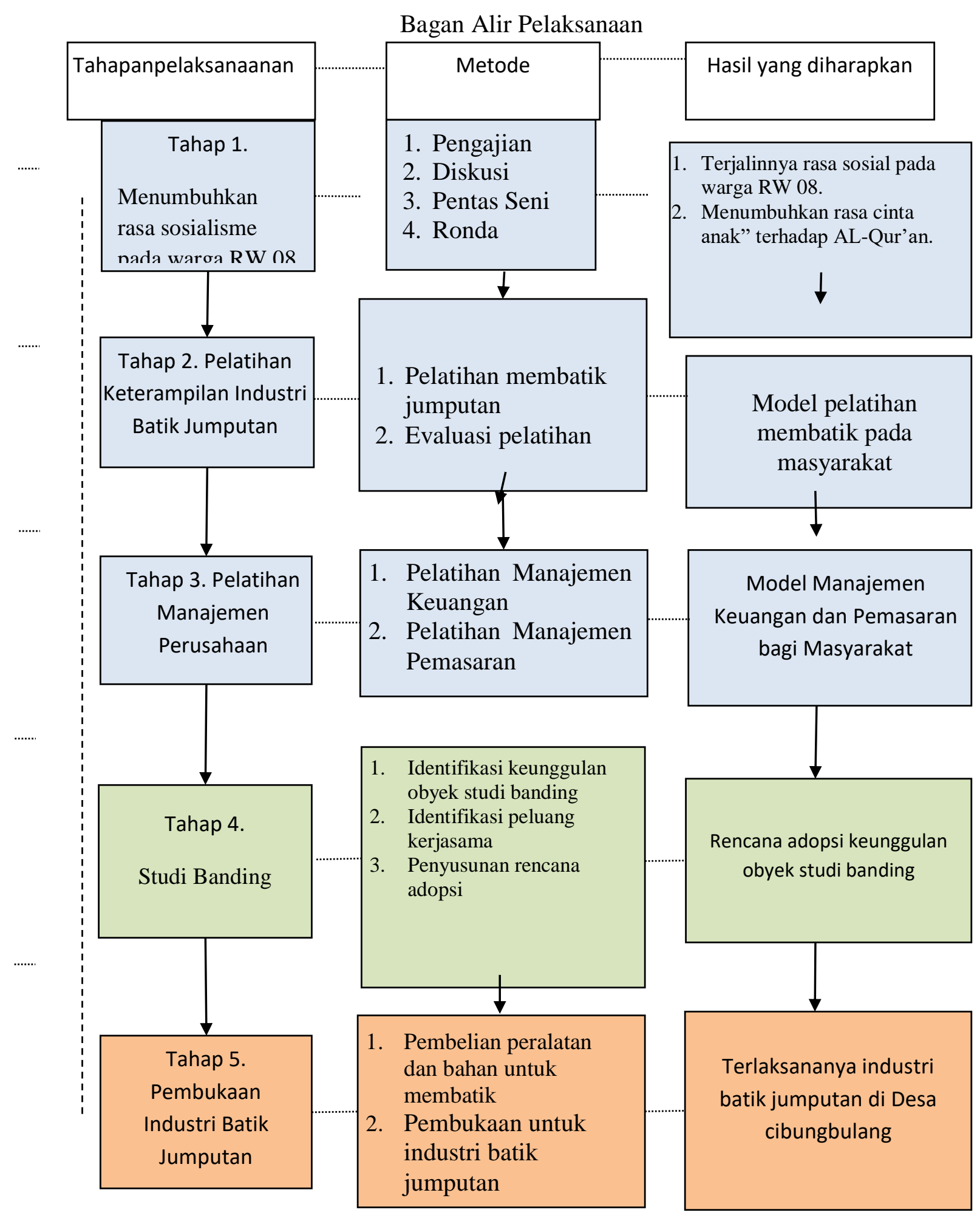


Jadwal Kegiatan

\begin{tabular}{|c|l|c|c|c|c|}
\hline \multirow{2}{*}{ No. } & \multicolumn{1}{|c|}{ Kegiatan } & \multicolumn{3}{c|}{ Minggu } \\
\cline { 2 - 5 } 1 & & 1 & 2 & 3 & 4 \\
\cline { 2 - 5 } & Penyusunan Rencana kegiatan & & & & \\
\hline 2 & Sosialisasi rencana kegiatan & & & \\
\hline 3 & Penyuluhan Kesehatan Cuci Tangan & & & \\
\hline 4 & Mengajar Mengaji di RW 08 & & & \\
\hline 5 & Pelatihan Batik Jumputan & & & \\
\hline 6 & $\begin{array}{l}\text { Pemasangan penerangan lampu jalan } \\
\text { menuju MCK }\end{array}$ & & & \\
\hline 7 & Pemasangan plang jalan di RW 08 & & & \\
\hline 8 & Kegiatan Ronda & & & \\
\hline 9 & Lomba 17 Agustus & & & \\
\hline 10 & Pentas Seni Kampung Pabuaran Semper & & & \\
\hline
\end{tabular}

\section{Metode Pendekatan}

Pendekatan yang digunakan dalam kegiatan ini adalah:

1. Pendekatan religius, yaitu pendekatan yang menggunakan nilai-nilai agama sebagai basis kegiatan. Pendekatan ini sangat penting karena permasalahan pemahaman radikalisme dalam masyarakat sangat dipengaruhi oleh faktor keimanan, pengalaman keagamaan, rasa tanggungjawab dan pengetahuan (Rachmawati, 2010).

2. Pendekatan organisasi, yaitu pendekatan dimana seluruh kegiatan diorganisir oleh Pondok Pesantren As Salaam dan SMP al-Ittihadiyyah. Hal ini sesuai dengan hasil penelitian Bahari (2010) dimana dia menemukan bahwa keterlibatan organisasi mempunyai pengaruh langsung terhadap toleransi.

3. Pendekatan kekerabatan, artinya bahwa pembinaan yang dilakukan senantiasa dikaitkan dalam rangka membangun kekerabatan antar jama'ah yang semakin memudar.
Nurhayati (2005) menemukan bahwa faktor pendukung toleransi umat Islam dengan Hindu adalah adanya sistem kekerabatan.

4. Pendekatan berdasarkan karakter masyarakat, yakni pembinaan yang dilakukan akan disesuaikan dengan karakter masyarakat. Joyce dan Weil (1996) mengungkapkan bahwa model pendidikan yang relevan dengan perilaku sosial dan nilai adalah dengan banyak memberikan permainan peran. Hal ini dilakukan untuk memberi pengalaman riil kepada peserta didik tentang sesuatu yang dilakukan atau dirasakan oleh orang lain. Memang, dalam prakteknya, tidak seluruh aspek harus menggunakan permainan ini. Dalam beberapa hal, terdapat kegiatan-kegiatan yang hanya golongan tertentu untuk melakukannya. Sejalan dengan konsep Joyce dan Weil, cooperative learning yang digagas Slavin (2005) dapat digunakan untuk membangun kesadaran toleransi masyarakat. Hal 
ini karena penekanan dari konsep pendidikan ini adalah kerjasama yang merupakan urat nadi toleransi. Dengan demikian, model pendidikan yang akan dibangun menggunakan dua konsep utama yaitu role playing model dan cooperative learning model.

\section{Partisipasi Masyarakat dalam Pelaksanaan Program}

Partisipasi masyarakat yang dapat dilakukan dalam kegiatan ini adalah sebagai berikut:

1. Mempersiapkan anak-anak SDN Leuweung Kolot 3 , kelas 3 dan 4 yang bersedia mengikuti penyuluhantentang perilaku hidup bersih dan sehat yaitu cuci tangan.

2. Mempersiapkan tempat untuk pembinaan dan pelatihan untuk membatik jumputan.

3. Mempersiapkan alat dan bahan untuk pemasangan penerangan jalan umum untuk akses ke MCK.

4. Pelaksanaan kegiatan lomba 17 Agustus dan acara puncak pentas seni dalam rangka memperingati hari HUT RI ke 73.

5. Mempersiapkan alat dan bahan untuk pemasangan plang petunjuk jalan bersama ketua RW 08 dan warga sekitar.

6. Meminta izin kepada ibu-ibu untuk membimbing anaknya dalam belajar mengaji.

\section{Langkah Evaluasi}

Evaluasi yang akan dilakukan terdiri dari:

1. Evaluasi proses, yang terkait dengan perencanaan, pelaksanaan dan monitoring kegiatan. Evaluasi proses akan dilakukan setiap pekan bersama dengan masyarakat.
2. Evaluasi hasil, yang akan dilaksanakan setelah kegiatan terlaksana . Evaluasi hasil untuk meningkatkan perekonomian SDM dan meningkatkan rasa sosial yang tinggi antar masyarakat.

3. Evaluasi dampak, yang akan dilakukan 6 (enam) bulan setelah pelaksanaan pembinaan. Evaluasi dampak diarahkan untuk melihat efektivitas model pembinaan dan keberlangsungan industri batik jumputan (Gall dan Borg,2003).

\section{HASIL DAN PEMBAHASAN}

\section{Bidang Ekonomi}
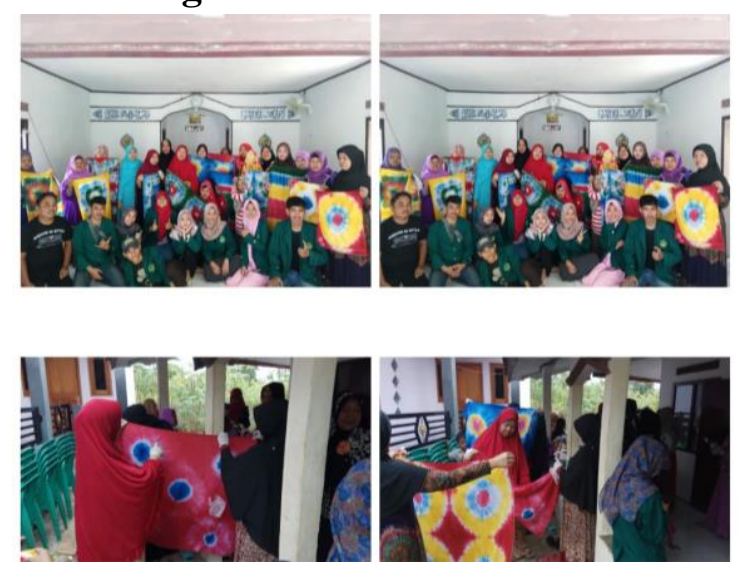

- Membuat kerajinan jumputan/ membatik

Membuat para ibu-ibu di desa girimulya bisa mempunyai keterampilan seperti membatik/jumputan 


\section{Bidang Kesehatan}
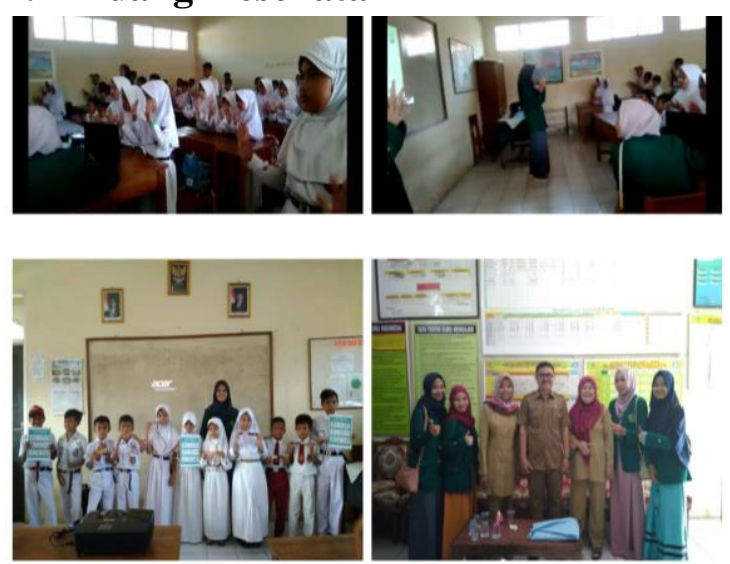

- Penyuluhan Kesehatan Cuci Tangan Terciptanya kehidupan bersih dan sehat di lingkungan Desa Girimulya

\section{Bidang Agama}
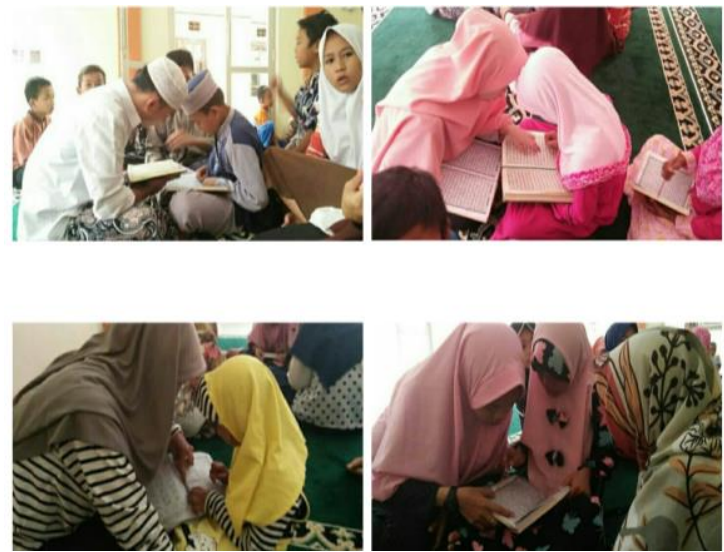

- Pengajaran TPA

Dapat memahami dan membaca Alqur'an dengan benar.

\section{Bidang Tekhnik}
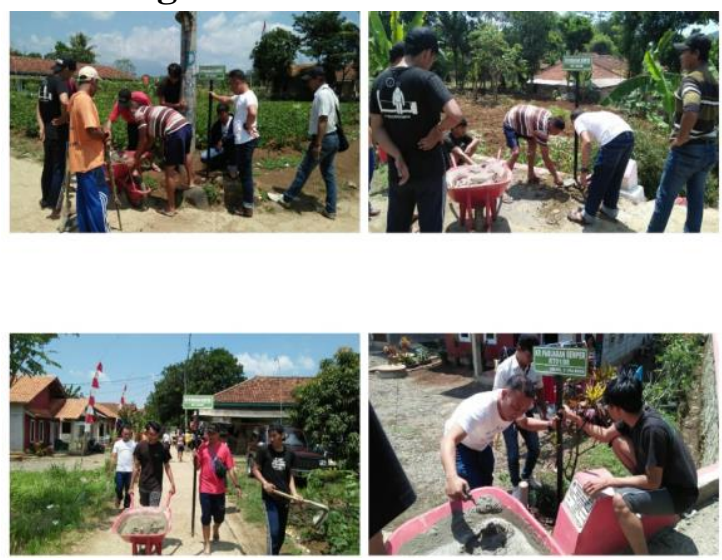

- Pembuatan Plang Jalan
Mengetahui nama jalan dan pembatas antar RT
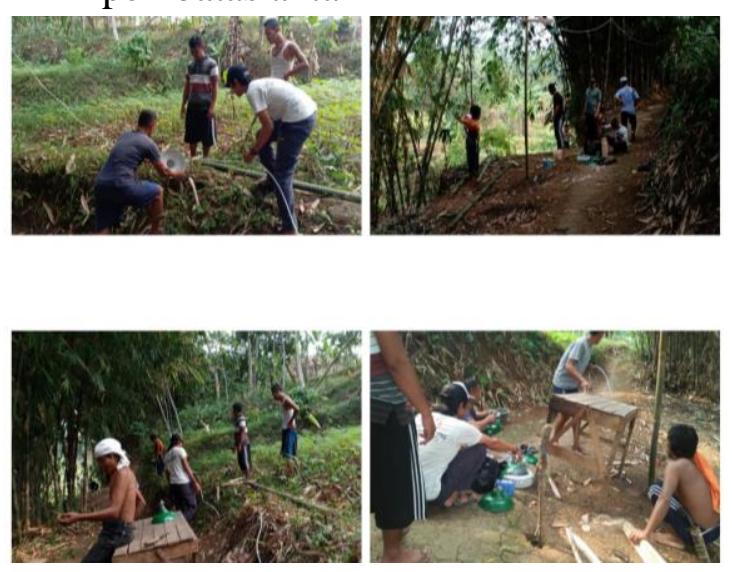

- Pembuatan penerangan jalan menuju tempat Pemandian

\section{Bidang Lainnya}
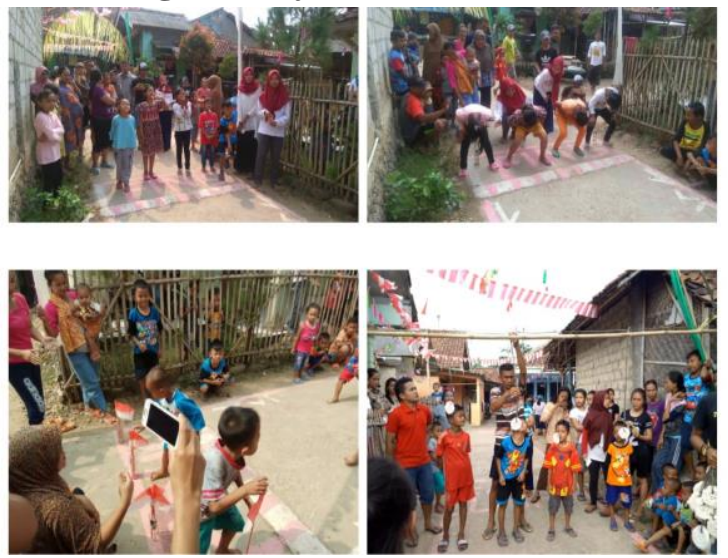

- Indonesia Independence day (17 Agustus 2018)

Menumbuhkan jiwa nasionalisme pada warga
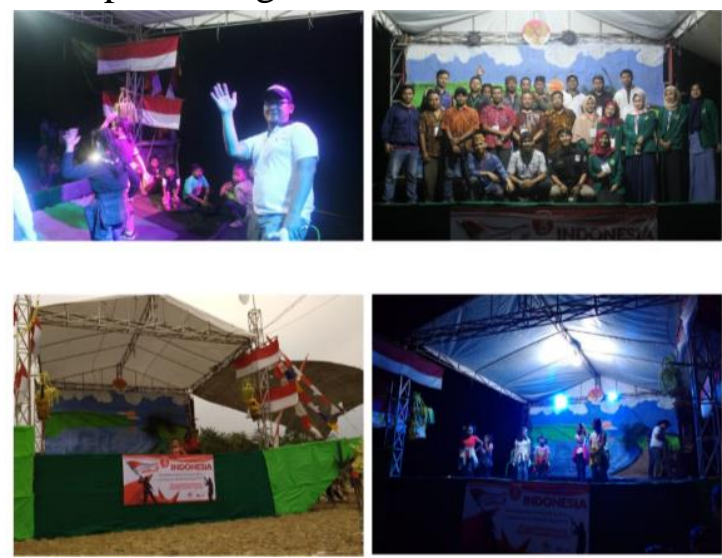

- Pentas Seni

Mempererat tali silaturahmi antara warga dan 


\section{KESIMPULAN}

Kesenjangan sosial dan ekonomi masyarakat adalah perbedaan tingkat kemampuan masyarakat baik dari segi pendapatan atau ketimpangan sosial dalam masyarakat yang menjadikan perbedan yang sangat mencolok antara masyarakat. Salah satu desa yang memiliki kesenjangan sosial dan ekonomi adalah Desa Girimulya Kecamatan Cibungbulang Kabupaten Bogor. Khususnya di RW 08 Kampung Pabuaran Semper, yaitu karena masyarakatnya bersifat individualis yang hanya memetingkan kelompok tertentu saja dan tingkat pendidikan masyarakat yang masih rendah Masyarakat sangat terbantu karena adanya mahasiswa KKN yang telah melaksanakan pengadian kepada masyarakat dan ikut serta dalam partisipasi kegiatan masyarakat.

\section{Dampak Bagi Masyarakat}

1. Ibu-ibu warga RW 08 merasa terpuaskan karena diadakannya pelatihan membatik jumputan.

2. Anak-anak menjadi mampu dalam melaksanakan praktek cuci tangan yang baik dan benar.

3. Masyarakat sangat terbantu dengan adanya penrangan jalan umum akses menuju MCK.

4. Masyarakat sangat terbantu dengan adanya plang penujuk jalan antar RT.

5. Ibu-ibu merasa sangat senang karena adanya pengajian untuk anak-anaknya.

6. Antusias warga dalam rangka perlombaan memperingati HUT RI ke 73.

\section{SARAN}

Semoga semua warga bisa menerapakan apa yang telah kami realisasikan untuk menumbuhkan tingkat perekonomian dan rasa sosial masyarakat RW 08 Kampung Pabuaran Semper Desa Girimulya Kecamatan Cibungbulang Kabupaten Bogor.

\section{REFERENSI}

Bahari. (2010). Toleransi Beragama Mahasiswa (Studi tentang Pengaruh Kepribadian, Keterlibatan Organisasi). Jakarta: Kementerian Agama RI Badan Litbang dan Diklat Puslitbang Kehidupan Keagamaan.

Gall, M. G. (2003). Educational Research an Introduction. Boston: Pearson Education, Inc.

Joyce, B. d. (1996). Models of Teaching. Boston: Allyn and Bacon.

Nurhayati (2005) menemukan bahwa faktor pendukung toleransi umat Islam dengan Hindu adalah adanya sistem kekerabatan.

Rachmawati, A. (2006). Toleransi Antar Umat Islam dan Katolik: Studi Kasus di Dukuh Kasaran, Desa Pasungan, Kecamatan Ceper, Kabupaten Klaten. Skripsi. Semarang: IAIN Walisongo.

Slavin, R. (2005). Cooperative learning: theory, research and practice. London: Allyn and Bacon. 